\title{
Evaluating the effect of fishery closures: lessons learnt from the Plaice Box
}

Beare, Doug; Rijnsdorp, Adriaan D.; Blæsbjerg, Mette; Damm, Ulrich; Egekvist, Josefine; Fock, Heino; Kloppmann, Matthias; Röckmann, Christine; Schroeder, Alexander; Schulze, Torsten

Total number of authors:

15

Published in:

Journal of Sea Research

Link to article, DOI:

10.1016/j.seares.2013.04.002

Publication date:

2013

Link back to DTU Orbit

Citation (APA):

Beare, D., Rijnsdorp, A. D., Blæsbjerg, M., Damm, U., Egekvist, J., Fock, H., Kloppmann, M., Röckmann, C., Schroeder, A., Schulze, T., Tulp, I., Ulrich, C., Hal, R. V., Kooten, T. V., \& Verweij, M. (2013). Evaluating the effect of fishery closures: lessons learnt from the Plaice Box. Journal of Sea Research, 84, 49-60.

https://doi.org/10.1016/j.seares.2013.04.002

\section{General rights}

Copyright and moral rights for the publications made accessible in the public portal are retained by the authors and/or other copyright owners and it is a condition of accessing publications that users recognise and abide by the legal requirements associated with these rights.

- Users may download and print one copy of any publication from the public portal for the purpose of private study or research.

- You may not further distribute the material or use it for any profit-making activity or commercial gain

- You may freely distribute the URL identifying the publication in the public portal 


\title{
Accepted Manuscript
}

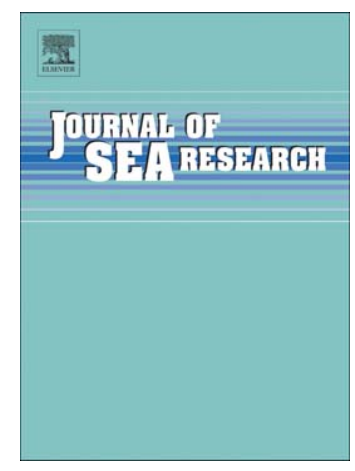

Evaluating the effect of fishery closures: Lessons learnt from the Plaice Box

Doug Beare, Adriaan D. Rijnsdorp, Mette Blaesberg, Ulrich Damm, Josefine Egekvist, Heino Fock, Matthias Kloppmann, Christine Röckmann, Alexander Schroeder, Torsten Schulze, Ingrid Tulp, Clara Ulrich, Ralf van Hal, Tobias van Kooten, Marieke Verweij

\author{
PII: $\quad$ S1385-1101(13)00067-1 \\ DOI: $\quad$ doi: $10.1016 /$ j.seares.2013.04.002 \\ Reference: $\quad$ SEARES 1068 \\ To appear in: Journal of Sea Research \\ Received date: $\quad 18$ April 2012 \\ Revised date: $\quad 19$ February 2013 \\ Accepted date: 5 April 2013
}

Please cite this article as: Beare, Doug, Rijnsdorp, Adriaan D., Blaesberg, Mette, Damm, Ulrich, Egekvist, Josefine, Fock, Heino, Kloppmann, Matthias, Röckmann, Christine, Schroeder, Alexander, Schulze, Torsten, Tulp, Ingrid, Ulrich, Clara, van Hal, Ralf, van Kooten, Tobias, Verweij, Marieke, Evaluating the effect of fishery closures: Lessons learnt from the Plaice Box, Journal of Sea Research (2013), doi: $10.1016 /$ j.seares.2013.04.002

This is a PDF file of an unedited manuscript that has been accepted for publication. As a service to our customers we are providing this early version of the manuscript. The manuscript will undergo copyediting, typesetting, and review of the resulting proof before it is published in its final form. Please note that during the production process errors may be discovered which could affect the content, and all legal disclaimers that apply to the journal pertain. 
Evaluating the effect of fishery closures: lessons learnt from the Plaice Box

Doug Beare ${ }^{\mathrm{a}, \mathrm{b} *}$, Adriaan D. Rijnsdorp ${ }^{\mathrm{a} *}$, Mette Blaesberg ${ }^{\mathrm{c}}$, Ulrich Damm ${ }^{\mathrm{d}}$, Josefine Egekvist $^{\mathrm{c}}$, Heino Fock ${ }^{\mathrm{d}}$, Matthias Kloppmann ${ }^{\mathrm{d}}$, Christine Röckmann ${ }^{\mathrm{a}}$, Alexander Schroeder ${ }^{\mathrm{e}}$, Torsten Schulze ${ }^{\mathrm{d}}$, Ingrid Tulp ${ }^{\mathrm{a}}$, Clara Ulrich ${ }^{\mathrm{c}}$, Ralf van Hal ${ }^{\mathrm{a}}$, Tobias van Kooten $^{\mathrm{a}}$, Marieke Verweij ${ }^{\mathrm{f}}$

a. Institute for Marine Resources and Ecosystem Studies (IMARES), Wageningen University \& Research Centre (WUR), P.O. Box 68, 1970 AB IJmuiden, The Netherlands

b. WorldFish, Jalan Batu Maung, 11960 Bayan Lepas, Penang, Malaysia.

c. Technical University of Denmark, National Institute for Aquatic Resources (DTU Aqua), Charlottenlund Castle, 2920 Charlottenlund, Denmark

d. Johann Heinrich von Thünen Institute, Federal Research Institute for Rural Areas, Forestry and Fisheries, Institute of Sea Fisheries, Palmaille 9, 22767 Hamburg, Germany

e. Alfred Wegener Institute for Polar and Marine Research, Am Handelshafen 12, 27570 Bremerhaven, Germany

f. ProSea Foundation, P.O. Box 428, 3500 AK Utrecht, The Netherlands

*These authors contributed equally to this work. 


\section{ABSTRACT}

To reduce discarding of plaice Pleuronectes platessa in the North Sea flatfish fisheries, the major nursery areas were closed to large trawlers in 1995. The area closed was named the 'Plaice Box' (PB) and beam trawl effort fell by over 90\%, while the exemption fleets of small flatfish beam trawlers, gill netters targeting sole (Solea solea) and shrimp (Crangon crangon) trawlers increased their effort. Contrary to the expectation, plaice landings and biomass declined. The initial support for the PB from the fisheries was lost, whereas other stakeholder groups claimed that any failure was due to the fact that fishing had never been completely prohibited in the area. To evaluate whether the PB has been an effective management measure, the changes in the ecosystem (plaice, demersal fish, benthos) and fisheries are analysed to test whether the observed changes are due to the PB or to changes in the environment unrelated to the PB. Juvenile growth rate of plaice decreased and juveniles moved to deeper waters outside the PB. Demersal fish biomass decreased, whereas the abundance of epibenthic predators (Asterias rubens and Cancer pagurus) increased in the PB. Endobenthos, in particular the main food items of plaice (polychaetes and small bivalves) remained stable or decreased both inside and outside the PB. Currently catches of both plaice and sole from within the PB are lower than in the late 1980s and the exemption fleet often prefers to fish outside the Plaice Box alongside much larger competitors. It is concluded that the observed changes are most likely related to changes in the North Sea ecosystem, which may be related to changes in eutrophication and temperature. It is less likely that they are related to the change in fishing. This case study highlights the importance setting testable objectives and an appropriate evaluation framework including both ecological and socio-economic indicators when implementing closed areas.

Key words: Marine Protected Area, MPA, spatial management, fisheries management, discards, climate change, trawling impact, North Sea, benthos, ecosystem change, stakeholder perception 


\section{INTRODUCTION}

Marine Protected Areas are a potentially useful tool in fisheries management helping to achieve sustainable fisheries and reducing negative ecosystem impacts. This stems from their relative simplicity, ease of enforcement and intuitive logic. The perceived failures of traditional methods of fisheries management worldwide with declining stocks, overfishing, and general fleet overcapacity (Worm et al. 2009, Pauly et al. 2002) have also contributed to the clamor for Marine Protected Areas to be set up (Sumaila et al. 2000, Kaiser 2005, Laurel and Bradbury 2006, Babcock et al. 1999). Furthermore some recent studies have shown that, in comparison with other human maritime activities, (e.g. oil and gas exploration, mineral dredging, and waste disposal) commercial fishing is by far the most important activity impacting marine ecosystems (Eastwood et al. 2007; Halpern et al., 2008; Röckmann et al., 2007).

In the context of sustainable fisheries management, modeling studies have shown that MPAs may be effective management instruments to reduce fishing mortality of exploited fish species or protect particular vulnerable life history stages (Hall, 1998; Hastings and Botsford, 2003; Miethe et al., 2010). MPAs are generally thought to influence fish stocks through two main mechanisms: "spill-over" and "export" (e.g. Higgins et al. 2008; Gell \& Roberts 2003). Spill-over is the net emigration of adults and juveniles across the reserve borders into the surrounding areas, while "export" assumes that when protected individuals reach maturity and spawn, their eggs and larvae will be carried to unprotected regions, supporting and enhancing populations outside the marine reserve boundary that may not have the same density of spawning adults (Gell \& Roberts 2003). Since dispersal characteristics and the scale at which dispersal occurs is largely unknown for many species (Carr \& Reed 1992; Gell \& Roberts 2003) export is often difficult to estimate. "Spill-over" will depend on the movements of the fish relative to the surface area of the MPA (Hall, 1998; Codling 2008; Murawski et al.2000; Higgins et al. 2008).

Empirical studies evaluating the performance of MPAs, however, are limited (Jennings, 2009; Vandeperre et al., 2011). There is compelling empirical evidence that MPAs have positive effects on fish species inhabiting tropical or temperate reef ecosystems, which have a rather sedentary life style (Claudet et al. 2008). The evidence for positive effects in temperate ecosystems, where fish species are characterized by seasonal migration patterns, is less clear. Positive effects of temperate MPAs have been observed in the northwest 
Atlantic, where large areas have been closed to fishing to protect depleted groundfish stocks and most, but not all, groundfish stocks recovered (Murawski et al., 2005). Recoveries in benthos and benthic habitats were also observed (Hermsen et al., 2003; Lindholm et al., 2004; Asch et al., 2008). A contrasting example is the Plaice Box (PB), an area in the North Sea that was partly closed to large $(>221 \mathrm{~kW})$ beam trawlers to reduce discarding of undersized plaice Pleuronectes platessa L since 1989 (Figure 1). Opposite to the expectation, the landings and biomass decreased since the establishment of the PB (Pastoors et al., 2000), resulting in a loss of credibility in fisheries management advice and a loss of support for Marine Protected Areas in general (Verweij and van Densen, 2010). The decrease in landings and stock, however, does not prove that the PB was unsuccessful, because the decrease might due to a deterioration in environmental conditions affecting the productivity of the stock. Hence for a proper evaluation of the PB and any closed area, we need to separate the effects of changes in fishing following the establishment of the closed area from the effects of changes in the environment that are not related to the area closure.

The difficulties in separating fishing from environmental impacts in the absence of reference areas can be overcome by combining modeling studies of key processes combined with empirical studies (Horwood et al., 1998; Pastoors et al., 2000; Kraus et al., 2009). The crucial question is the extent to which the establishment of a closed area might trigger negative feed-back processes that may reduce the intended effect of a closed area. Figure 2 shows the processes affecting plaice recruitment relevant for the PB evaluation. A cohort starts with the larval supply of number of individuals that survive the pelagic egg and larval phase and settle on the nursery grounds inside (1a) and outside the PB (1b). The duration of their discard phase is affected by the growth rate (2), which may be affected by densitydependent processes that may differ inside (2a) and outside (2b) the PB. The discard mortality rate will depend on the fishing effort (3) inside and outside the PB and will be affected by the relative larval supply to the two areas $(1 \mathrm{a}, 1 \mathrm{~b})$ and the movement of undersized plaice between the PB and the areas outside the PB (4). Finally, recruitment will be affected by natural mortality processes (5).

Negative feed-back processes to consider are density-dependent effects in growth rate (Lorenzen and Enberg, 2002), natural mortality (Modin and Pihl, 1994), and changes in distributions (Shepherd and Litvak, 2004). Another negative feed-back process is the response of plaice to trawling disturbance (Kaiser et al. 2006). Based on general ecological 
theory one may expect larger long-lived species to be negatively affected by bottom trawling, while small opportunistic species will benefit due to a reduction of competition or predation by larger benthic organisms (Jennings et al., 1998). Since plaice feed on small opportunistic species (Rijnsdorp and Vingerhoed, 2001), a reduction in bottom trawling within the PB may reduce the food relative to areas outside the PB (Hiddink et al. 2008) and affect both growth rate and spatial distribution (Rijnsdorp and van Leeuwen, 1996; van Keeken et al., 2007). Such a mechanism has been suggested by fishers as the most important reason for the perceived failure of the PB management measure. They maintain that the seabed must be 'ploughed' in order to speed the growth of benthos edible to plaice (Verweij and van Densen, 2010).

In addition to ecological processes, the performance of closed areas will also be affected by the social, economic and institutional dimensions which are critical to their success (Charles and Wilson, 2009; Jennings, 2009).

The objective of the paper is to evaluate the performance of the PB. In particular we question whether the decrease in the stock in the 1990s was due to feed-back processes from the changes in fishing caused by the establishment of the $\mathrm{PB}$, or due to environmental changes unrelated to PB. We will (1) review the history of the Plaice Box, focusing on the management process that led to the establishment of the PB and its subsequent series of evaluations, with a focus on the role of fishing industry, conservation groups (NGOs), fisheries scientist and the fisheries managers; (2) review the changes in fishing following the establishment of the PB; (3) review the changes in the abiotic environment and ecology of the PB focusing on the (i) population biology of plaice; (ii) the fish and benthic community; (4) analyze the socio-economic consequences; and (5) derive general management recommendations for MPAs.

In our review, we analyse the changes in four areas: (1) the PB area inside the $12 \mathrm{~nm}$ limit, 'in-in'; (2) the PB area outside the $12 \mathrm{~nm}$ limit 'in-out'; (3) the area outside the PB but inside the $12 \mathrm{~nm}$ limit, 'out-in' and (4) the area outside the PB and outside the $12 \mathrm{~nm}$ limit, 'out-out' (Figure 1). The rationale for this area classification is that it distinguishes the area that is mostly affected by the PB regulation (in-out) from the areas that are likely less affected (in-in) and not or only indirectly affected. In-in represents the area protected by 
EEC 2527/80 since 1981.

\section{HISTORY OF THE PLAICE BOX}

\section{The establishment of the Plaice Box}

The concern about the bycatch of small plaice in the bottom trawl fisheries goes back to the beginning of the $20^{\text {th }}$ century when fisheries scientist advocated closing coastal nursery grounds to protect juveniles (Anon., 1913, 1921; Mielck, 1926). Survival of plaice discards is negligible (van Beek et al., 1990; Berghahn et al., 1992). The bycatch problem was taken up again by the International Council for the Exploration of the Sea (ICES) in the late 1980s showing that an increase in mesh-size would certainly reduce the plaice bycatch but simultaneously render the sole fishery unviable economically (ICES, 1987). Closure of the coastal waters in the 2nd and 3rd quarters, in which $90 \%$ of the undersized plaice then occurred, would enhance plaice yield by $26 \%$, and by $36 \%$ if closed year round (Table 1 ). The advice was based on a yield / spawning stock biomass per recruit approach in which the exploitation pattern was changed in accordance to the change in mesh size or spatial and seasonal distribution of fishing effort relative to plaice. The explicit assumption was that all other conditions such as recruitment, growth, natural mortality and spatial distribution, would remain unchanged. Sole survival would also increase but the benefits would not be so pronounced (Rijnsdorp et al. 1991).

The advice was discussed in the relevant European Union Member States. Representatives of the Dutch fishing industry, for example, supported the idea, although they criticized the choice of borders which were subsequently altered after a consultation process. With support of the major stakeholders, the EU then inaugurated the PB in 1989 (EU Council Resolution 4193/88). The PB encompasses an area of circa $42,000 \mathrm{~km}^{2}$, of which circa $24,000 \mathrm{~km}^{2}$ is located within the $12 \mathrm{~nm}$ zone (Fig. 1). Initially the PB applied only to the $2^{\text {nd }}$ and $3^{\text {rd }}$ quarter, but in 1994 the regulation was extended to the $4^{\text {th }}$ quarter and in 1995 it was closed year round for any demersal trawler exceeding $221 \mathrm{~kW}$ main engine power. Fishing by other gear categories, such as beam trawlers and shrimpers of $<221 \mathrm{~kW}$, was permitted as these fleets were considered to have no alternative to fish further away from their ports. For these fleets, which already had rights to fish within the $12 \mathrm{~nm}$ zone, the PB implied an extension by $75 \%$ of their exclusive fishing area. 


\section{Plaice Box evaluations}

Table 2 shows the topics studied in the successive evaluations of the PB. The first evaluation (ICES, 1994) showed how fishing effort in the PB increased each October when large beam trawlers entered and estimated the effect of a year round closure on the yield and SSB of plaice and sole (Table 1). This information formed the basis for the extension of the PB into the $4^{\text {th }}$ quarter in 1994 , and the entire year from 1995 onwards. The $2^{\text {nd }}$ evaluation in 1999 concluded that, in contrast to the expected positive effects, yield and spawning stock biomass of plaice had declined, that the growth rate of plaice had decreased, and that young plaice had been displaced offshore (ICES, 1999). The $3^{\text {rd }}$ evaluation also noted the offshore movement of the small plaice and stressed the difficulties involved in separating the important competing effects (e.g. fishing effort versus climatic changes) from one another (Grift et al. 2004). No 'designed experiment' had been done and only observational data were available rendering firm, statistically-backed conclusions impossible.

In May 2004 the EU reviewed Article 19 of Council Regulation No. 2371/2002, which controls access to waters outside the $12 \mathrm{~nm}$ zone, stating that a wide consultation of stakeholders on the future of the Plaice and Shetland Boxes should take place. To that end they circulated a discussion paper to interested parties including the North Sea Regional Advisory Committee (NSRAC). The NSRAC, in which representatives of fisheries and NGOs discuss fisheries management issues, stated that fishing activity within the PB by some fleet segments had actually intensified, and that poor enforcement of engine power limitations was an area of concern. They emphasized that there had been a lack of clear objectives when the PB was established, which had hindered its subsequent ecological assessment. The NSRAC suggested that experimental research could enable some mechanisms within the PB to be measured. Both potential negative effects of the closed area (i.e., a lower benthic productivity due to the lack of trawling disturbance, a hypothesis advocated by the Dutch flatfish fisheries) and potential positive effects (better survival of undersized plaice) could then be assessed. It was stressed that any evaluation of the PB should not be seen in isolation from a wider discussion on protected areas as a management instrument for fisheries and ecosystems. They also assumed that the PB had become important in the socio-economic welfare of the small-scale coastal fisheries. Against this background the NSRAC advised that another scientific evaluation of the PB should be 
carried out.

As far as EU member state governments were concerned, comments on the discussion paper were only received from two (Commission of the European Communities 2005). The UK had no firm position on the future of the PB while Germany was strongly in favor of its retention; and possibly even of its expansion further west, in order to protect the juvenile plaice now found there. Germany also advocated better enforcement of the $221 \mathrm{~kW}$ limit on vessel engine power and an investigation into the impact of twin-trawling in the area. In response, the Commission stated that any modifications to the $\mathrm{PB}$ on an experimental basis would be very difficult to organize and enforce. Vociferous objections from the German fishing industry to any changes in access to the PB further demonstrated future potential obstacles. The Commission, therefore, accepted in principal the proposal to study the issue further, but in the meantime stated that the status quo regarding access would be maintained. It was also stressed that the proper access restrictions would be properly and rigorously enforced, particularly with respect to engine power. The suggestions of the NSRAC eventually led the Commission to fund a $4^{\text {th }}$ evaluation in 2009 (see Beare et al. 2010).

\section{CHANGES IN FISHING}

The métiers that are the most important in terms of their contribution to plaice catches are presented in Table 3 (see also SOM). For each métier, distinction was made between vessels $<=221 \mathrm{~kW}$ and those $>221 \mathrm{~kW}$, because of the latter are not allowed to fish within the $12 \mathrm{~nm}$ zone and the PB.

Pre Plaice Box period (1984-1988) Our ability to determine the precise details of fishing activity during the immediate pre-PB period is hampered by difficulties acquiring data at the necessary resolution. The most significant component of fishing in the area were, by far, the large Dutch beam trawlers (> $221 \mathrm{~kW})$ which were fishing beyond the $12 \mathrm{~nm}$ zone (Table 3). Average fishing effort by this category was 1232 million kWh between 1984 and 
1988 , of which $16 \%$ was exerted inside the PB. The PB was also important to the small beam trawlers with $50 \%$ of the average fishing effort being exerted there (20 million $\mathrm{kWh}$ ). In contrast, total Danish fishing effort by all gears was only 4.75 million $\mathrm{kWh}$ inside the PB in 1988.

Plaice box period Total fishing effort by Dutch beam trawlers inside the PB fell in 19891994 to $15 \%$ of the pre-box level and to 3\% in the period 1995-2008 (Table 5). The large beam trawlers clearly reacted to the seasonal opening of the PB between 1990 and 1993 with spikes in fishing effort (Fig. 3) during quarter 4 between 1990 and 1993 when the PB was temporarily opened. The other important fleet of Danish gill and trammel netters, expanded their fishing effort rapidly after closure to the large vessels (see Fig. 3). Between 1995 and 2008, fishing effort by all métiers has decreased (Fig. 3), except for the shrimp trawlers (BEAM 16-31mm). The decrease occurred both within and outside the PB but was particularly pronounced in the PB. The percentage of landings of sole, plaice and cod caught inside the PB (as compared to outside the PB) decreased in this period, while the percentage of brown shrimp increased (Fig. 4).

Detailed patterns of fishing effort (total hours fished per year) for the most important métiers are shown for 2008 (Fig. 5). For the $<=221 \mathrm{~kW}$ category the shrimpers are the most important fleet. This fleet fishes intensively within the PB and there has not been much spatial variation between years. Overall, the PB is the most important area for shrimp trawlers (Table 4), although around $90 \%$ of the effort is achieved within the $12 \mathrm{~nm}$ zone. Gill netters show two main concentrations of activity both within and outside the PB. The small beam trawlers mainly work within the $12 \mathrm{~nm}$ zone off the coast of Belgium and the Netherlands with lower activity along the inside border of the PB. The larger beam trawlers targeting sole and plaice (> 221kW) adhere strongly to the regulations and work outside the PB with higher activity along borders of the PB, in particular in the German Bight. Otter trawlers fishing for sole, plaice and Nephrops, both $<=221 \mathrm{~kW}$ and $>221 \mathrm{~kW}$, operate mainly outside the PB although there is some activity, particularly by boats with larger meshes, within the northern parts of the PB off the west coast of Denmark. Otter trawlers fishing > $100 \mathrm{~mm}$ mesh are not restricted by the PB regulations (EC 850/98) and large Danish vessels, targeting plaice also exploit grounds inside the PB to some extent, mainly in the north. It is noteworthy that the small vessels, using both otter and beam trawl targeting sole and plaice, partly fish in the same areas as the large vessels outside the PB; 
despite the fact they have the right to fish inside it (Figs 5a,b).

\section{4..CHANGES IN THE ENVIRONMENT AND ECOLOGY}

The actual data used, together with some metadata and other details of analytical approach are given in SOM.

\section{Environmental variables}

Since the establishment of the PB, environmental conditions have changed. In particular temperatures have increased in both winter and summer, whereas the input of inorganic nutrients important in promoting primary production (e.g. phosphate) has fallen ( Fig. 6).

\section{Benthic invertebrates}

The abundance of endobenthos reached peak values around 1980 and decreased to a lower level since the mid-1980s both within and outside the PB (Fig. 6). The abundance of the main prey species of plaice (polychaetes and small bivalves) showed a similar temporal development. The time trends of endobenthos in the PB were close to those observed within the $12 \mathrm{~nm}$ zone.

The total number of polychaetes increased between 1970 and 1980 when numbers peaked. Since then they have fallen steadily (Fig. 6). The overall levels, however, are on average two to four times higher inside the PB and in the $12 \mathrm{~nm}$ zone than outside the PB.

Small bivalves showed a similar pattern as the polychaetes with an increase between 1970 and the early 1980s followed by a decline. Unlike the polychaetes, however, there is a peak in the abundance of bivalves in all areas in circa 2000 (Fig. 6).

The epibenthic predators Cancer pagurus and Asterias rubens were more abundant inside the PB and showed a marked increase in abundance as compared to the area outside the PB (Fig. 6). The increase mainly occurred since the mid-1990s. The predatory whelk Buccinum undatum occurred in similar numbers in the PB and outside the PB with temporary peaks in abundance in all areas.

\section{Demersal fish}


The catch rate of demersal fish in the beam trawl survey in the PB showed an overall decline from over $300 \mathrm{~kg} \cdot \mathrm{h}^{-1}$ in the late $1980 \mathrm{~s}$ to around $75 \mathrm{~kg} \cdot \mathrm{h}^{-1}$ in the $1990 \mathrm{~s}$ and $2000 \mathrm{~s}$. Catch rate in the area outside the PB varied around 75 kg.h ${ }^{-1}$ (Fig. 6). The Shannon-Wiener diversity index $\mathrm{H}$ was lowest at the beginning of the time series for all areas (Fig. 6 and see also Beare et al., 2010) and increased until 1995 followed by a sharp drop in 1996 probably caused by the cold winter. Subsequently, diversity increased again to values between ca 1.5 and 2.0 and remained more or less stable until the end of the time series. The time trends in biomass and diversity of demersal fish in the PB closely resembled those observed within the $12 \mathrm{~nm}$ zone (Tulp et al., 2008).

\section{Plaice}

After the instigation of the PB the spawning stock biomass and annual yields have decreased substantially (Fig. 6). Recruitment has increased in the 1980s and appears to have remained stable since then. Juvenile growth rate showed a dome-shaped pattern with relatively high growth in the 1970s and a decrease since the mid-1980s. The changes in growth are reflected in the changes in the length of the time-period small plaice might be vulnerable to discard mortality, ie. 'the discard phase' (Fig. 6). The discard phase duration in the period of high growth in the decade prior to the PB was around 1 year and increased by $20 \%$ to 1.2 year in the 2000 s (Fig. 6). The increased discard phase duration in the $1990 \mathrm{~s}$ and 2000s coincides with a change in the distribution of plaice towards deeper waters further offshore. As a result, the proportion of the plaice present in the PB has gradually waned from about $90 \%$ (discard size class $15-26 \mathrm{~cm}$ ) in the 1980s and early 1990s to about $40 \%$ in the mid 2000 (Fig. 6).

Plaice discard rates are dependent on gear selectivity, fishing activities by area and season, and plaice size composition. Discard rates increase when strong year-classes appear in the fishery (Fig. 7, upper panel). Otter trawlers produce less discards than beam trawls. Spatial patterns of discard rates for otter trawlers and large beam trawlers based on GLM modeled observer data (Fig. 8) indicate increased discard rates off the West Frisian front. Instead, highest discard rates for small beam trawlers are found in the inner German Bight. Only three discard sampling years were available for the shrimp fisheries. Discard estimates for the shrimp fisheries employing a year-class effect model to account for temporal variability 
back-calculated to 1993 indicate peak by-catch for 1996 (Fig. 7 lower panel) with 1498 million 0-group specimens, of which some 650 million were caught in the German shrimp fisheries. Discards by fleet indicate that the major fraction is obtained by large beam trawlers outside the PB (Table 5).

\section{SOCIO-ECONOMIC CONSEQUENCES}

For plaice and sole landings, by far the most important fleets are the large beam trawlers which caught circa 20,000 t of plaice and around 10,000 t of sole annually between 1995 and 2008. Landings of these two species by the $<=221 \mathrm{~kW}$ fleet are much lower in comparison. The relative importance of the PB for landings of plaice and sole by the $<=221 \mathrm{~kW}$ fleet category has declined markedly between 1995 and 2008. However, the PB remains an important fishing area for some national fleets (e.g. the German fleet with $>70 \%$ of revenues from plaice and sole gained within the PB (see also Beare et al. 2010)). For the three investigated national fleets in total the majority of the plaice were taken outside the PB by large beam trawlers and otter trawlers fishing > $100 \mathrm{~mm}$ mesh. In 2008, the exemption fleet $(<=221 \mathrm{~kW})$ also took most of its plaice outside $(7,800 \mathrm{t})$ the PB in spite of being allowed inside (7,800 t outside versus $1596 \mathrm{t}$ inside). This pattern was the same for sole with the bulk $(8,014 \mathrm{t})$ being taken by large beamers outside the PB. Static netters $<=221 \mathrm{~kW}$ took the most sole inside the PB $(237 \mathrm{t})$ but nevertheless caught more outside (384 t). In the shrimp fishery the relative importance of the PB increased from 63\% in 1995 to $94 \%$ in 2008 (Fig. 4).

Shrimp landings by the combined Danish, Dutch and German fleets were 29,800 $t$ in 2008, and they were nearly all taken by $<=221 \mathrm{~kW}$ vessels inside the PB (Table 4). Only $14 \%$, 4\%, and 2\% for The Netherlands, Germany and Denmark (mean of 2005 to 2008), respectively, of monetary yield from shrimpers was earned outside the $12 \mathrm{~nm}$ zone but within the PB. For cod the pattern was relatively stable over time with the exemption fleet taking around $20 \%$ of their catches in the PB (Fig. 4).

After instigation of the $\mathrm{PB}$, the large beamers were removed and the competitive balance between fleets changed. Data suggest that effort by $<=221 \mathrm{~kW}$ Dutch beamers and 'others' increased inside the PB between 1990 and 1994 but fell sharply in 1995 when the PB was closed year round. Similarly effort by small Danish static netters increased between 
1987 and 1995 and then fell again. From about 2000 the PB started to become much less important to the exemption fleet (see Fig. 4) for its catches of finfish (plaice and sole) with $28 \%$ of plaice being caught in the PB in 2000 and $40 \%$ of sole, against $17 \%$ and only $21 \%$ in 2008 respectively. This reduction coincides with a decrease in the food availability inside and outside the PB (see Fig. 6), particularly in the case of bivalves; the levels of which became much higher even in a historical context. The signal is also reflected in a drop in the overall abundance of demersal fish in the PB (Fig. 6). It should be noted that many of the changes in the commercial fishery are unlikely to be driven only by the availability of the fish themselves. Fleet structure and effort allocation also evolve due to changes in quota for sole and plaice, increases in fuel costs, and other aspects of the fisheries management regime (Rijnsdorp et al. 2008; Poos et al., 2010). Hence many of the temporal trends in fishing effort (total kWhrs per year) observed in different categories of the exemption fleet are similar both outside and inside the PB.

The situation in 2005-2008 is summarized from VMS data in Table 4 in terms of percentages of effort, catch and monetary value. It shows that over $80 \%$ of the earnings by small $(<=221 \mathrm{~kW})$ shrimpers were made inside the PB but that the small beamers targeting plaice and sole derive only $19 \%$ of their earnings from the area. The PB is also important to large static netters, mostly registered to Denmark, where they get $32 \%$ of their revenues.

\section{LESSONS TO BE LEARNT}

The objective of this paper was to evaluate the effectiveness of the PB as an example of a partially closed area established to reduce the discarding and improve the sustainability of the fisheries. Understanding how the PB has affected the ecology and fisheries is important because the PB is considered to be a failure by some stakeholders (especially the fishermen) , has jeopardized the credibility of fisheries science and eroded the support for MPAs as effective tools for fisheries management (Verwij and van Densen, 2010).

The main changes that have occurred in plaice after the establishment of the PB is the decrease in the growth rate of juveniles (Rijnsdorp and van Leeuwen, 1996; Beare et al., 2010) and the offshore shift in distribution of juvenile plaice (Grift et al., 2004; van Keeken et al., 2007). The key question is whether the observed changes in growth and distribution 
are caused by the instigation of the PB which resulted in a 97\% reduction in trawling with heavy tickler chain trawls, or whether the observed changes are related to changes in environmental conditions that are unrelated to the instigation of the PB.

The increase in the epibenthic predators Asterias rubens and Cancer pagurus is consistent with a reduction in fishing mortality due to beam trawling in the PB. Cancer pagurus is a long lived crab that suffers substantial trawling mortality by bottom trawlers (BeukersSteward et al., 2001). Ramsay et al (2000) showed that the abundance of Asterias rubens increased with trawling intensity up to about 0.8 year $^{-1}$ and decreased with higher trawling intensities. Since beam trawl intensity in the coastal waters of the North Sea may reach values as high as 3-8 year $^{-1}$ (Rijnsdorp et al. 1998), the reduction in beam trawling in the PB is consistent with the observed increase in the abundance of Asterias rubens.

It is unlikely, however, that the decrease in endobenthos and the demersal fish is directly related to the decrease in beam trawling within the $\mathrm{PB}$, since similar time trends occurred within the $12 \mathrm{~nm}$ zone and outside the PB. Whether the decrease in endobenthos is due to the increase in epibenthic predators like $A$. rubens and $C$ pagurus remains to be studied.

Despite the substantial reduction in beam trawling within the PB, none of the biological time series showed changes coinciding with the instigation of the PB that were exclusive for the affected area. The changes in fish and benthos observed within the PB closely resembled the changes observed within the $12 \mathrm{~nm}$ zone of the PB. This observation makes it unlikely that the sharp reduction in beam trawling within the PB but outside the $12 \mathrm{~nm}$ zone is the dominant factor. The observed changes in the benthos and demersal fish of the southeastern North Sea are more likely related to changes in environmental conditions that are unrelated to the establishment of the PB. Contemporaneous with both main changes in the PB regulations (ie. 1989 and 1995) sudden changes in the physical and biological environment have been reported for the North Sea (Weijerman et al. 2005) by other authors working in different contexts, which may have confounded the effect of the PB. Examples of the major changes in the environment of the North Sea are: the increase in temperature since 1989 (Wiltshire and Manly 2004): and the decrease in nutrients (Heath and Beare 2008).

The decrease in growth of juvenile plaice, although coinciding with a similar decrease in their main food (endobenthos), is unlikely to be related to the decrease in trawling impact 
within the PB. The fall in food availability is more related to a decrease of benthic production probably precipitated by declining levels of nutrients like phosphate (Fig. 6) and nitrate (Heath and Beare, 2008). Similarly the rise in food availability, particularly bivalves, in the early 2000s (Fig. 6) in- and outside the PB is unlikely to be related to trawling activity that steadily decreased during the same period (Fig. 3a). This interpretation is supported by the analysis of inter-annual variations in growth of the 0-, 1and 2-group plaice that did not reveal a significant effect of sea bed disturbance (Beare et al., 2010). Significant effects were found for stock size (negative), eutrophication (positive) and temperature (positive for 0-group). The density-dependent effect was relatively small a $10 \%$ increase in density resulted in a $0.4-0.8 \%$ decrease in growth rate or length at age and insufficient to explain the decrease in growth observed (Beare et al., 2010). This updated analysis contrasted to the results of a previous study using data up-to 1994 which suggested a positive effect of sea bed disturbance on growth (Rijnsdorp and van Leeuwen, 1996).

The offshore movement of juvenile plaice is consistent with a behavioral response to steadily increasing temperatures (Teal et al., 2012).

It should be stressed here that it is the general North Sea wide reduction in fishing mortality, due to the substantial decreases in the fishing effort, which have allowed the plaice stock to increase (see Fig. 6); despite the continued high level of discarding (Aarts and Poos, 2009).

\section{Importance of setting objectives and an evaluation framework}

The experience of the PB has taught us the value of setting clear and inviolable objectives at the outset as well as designing a framework for evaluating its effectiveness. Initially the instigation of the PB was considered as a "Technical Fisheries Management" initiative to reduce discarding and improve plaice yields and biomass. Literally (EU Council Resolution 4193/88) "to establish seasonal limitations on certain fishing activities in the North Sea in order to limit fishing on juvenile plaice". At the time it was strongly supported by fishermen. Non Governmental Organizations (NGOs) were not involved in the process in the early stages. Since then the PB issue has become entangled with the conservation lobby and the worldwide debate (Laurel and Bradbury 2006) on Marine Protected Areas since it 
seemed likely that the PB restrictions might affect nature conservation (Lindeboom and Bäck 2005) and the area's economy. As a consequence various stakeholders suggested new objectives for the PB far exceeding its original remit. It should be stressed here that general conservation and protection of marine biota were never original objectives of the PB.

Assessment of the utility of the PB has been hampered during its history since it was not set up so that it could be scientifically evaluated. The same problem has been observed when similar restrictions have been introduced in other north European areas such as the Shetland Box, the Cod Box and the sandeel box (Horwood, 1998; Dinmore et al., 2003; Greenstreet et al., 2006). Careful monitoring of the economics of the commercial fleets, the fish resources, the ecosystem, and any changes in the environment is important for realistic evaluations (Kraus et al. 2009).

\section{Role of science in settling the debate among stakeholders}

NGOs consider the PB as a useful management measure as it has reduced the impact of the flatfish fisheries using heave trawl gear. Flatfish fishermen perceive the PB as a 'disasterstory' or 'the biggest management-mistake ever made'. They say the PB is a 'dead zone' for plaice and that only seastars (Asterias rubens) and brown crabs (Cancer pagurus) remain in the area. The decline of the plaice stock in the early 1990s was ascribed to a reduction of trawling disturbance in the PB coupled with decreased levels of dissolved phosphates in the sea water. Many fishermen agree that 'ploughing the seafloor' can supply food for plaice. There is also support for this theory from scientists (Hiddink et al, 2008) who show that certain levels of bottom trawling disturbance may enhance the production of food for plaice (small invertebrates), although a recent study suggested that fish condition was negatively related to trawling intensity (Hiddink et al., 2011). The fishermen argue that they are now actually an important part of the ecosystem itself working to enhance marine productivity. Our results, did not find support for the 'ploughing the seafloor' hypothesis, but also did not refute the hypothesis. This highlights the need for a dedicated experimental study to quantify the impact of bottom trawling on benthic ecosystem and the productivity of food for flatfish that are able to distinguish between the effects of trawling and the effects of changes in other environmental variables such as climate change or eutrophication.

The PB had a different effect on the various fisheries. The large flatfish beamers lost 
important fishing grounds inside the $\mathrm{PB}$ and were displaced to more distant fishing grounds. Although the exemption fleets $(<=221 \mathrm{~kW})$ are allowed to fish in the PB in the absence of competition from the larger vessels, their effort in, and landings from, the PB, relative to the rest of the North Sea have fallen. The real beneficiaries, therefore, have been the shrimpers showing a steady increase in effort, landings and earnings (Fig. 3).

The reputation of science and scientific advice has been damaged by the general failures of (partially) closed areas such as the PB. Fisheries scientists were naïve not to take the potential socio-economic, political, and governance dimensions into account. In the case of the PB, the almost immediate decline in overall North Sea plaice yields, its failure to protect the juveniles due to migration, and subsequent inability to quantify the impact of environmental change have all conspired to undermine the credibility of fisheries science. The fact that so much of the small plaice population lives outside the PB now renders any positive effects very small (see Table 1). This has all been reflected in a loss of support among the fishing industry for MPAs, which will no doubt frustrate the eventual realization of a network of MPAs to achieve biodiversity and conservation obligations (Verweij and van Densen 2010). However, the PB was never intended as a closed area and cannot be expected to have such effects.

The story of the PB also highlights how poorly we still understand marine ecosystems, and the difficulties scientists have predicting how they will react to stimuli such as changing fishing effort. Parallels have been seen in other situations such as the case of the Moray Firth bottlenose dolphins Tursiops truncatus which moved out of the estuary, southwards to the waters around the Scottish town of St. Andrews when the area they occupied received some protection (Wilson 2008). Whether such changes are, however, directly related to the reduced fishing effort or motivated by some other parallel factor, is at present in many cases not clearly answerable.

\section{Political considerations}

The PB ought to have been considered as a 'Technical Fisheries Management Measure"; functionally an extension of the $12 \mathrm{~nm}$ zone. It should be remembered that the decision to close the area was political and any future decisions to keep it closed will also be essentially political. At the outset, scientific advice was restricted to biological information and no attention, whatsoever, to any socio-economic consequences was paid. Furthermore the 
question as to whether the positive or negative effects of the PB could ultimately be assessed was not asked.

\section{ACKNOWLEDGEMENTS}

We would like to thank the European Commission (Directorate-General for Maritime Affairs and Fisheries) for funding the project, "Study for the revision of the plaice box" (Contract SI2.530000) on which the current work is based. The CGIAR Research Program on Climate Change, Agriculture and Food Security (CCAFS), which is a strategic partnership of CGIAR and Future Earth funded the final production of this manuscript. Other colleagues at IMARES provided invaluable help and advice including Floor Quirijns, Stijn Bierman, Charlotte Deerenberg and Jan-Jaap Poos. A debt of thanks is also due to representatives of the Dutch fishing industry, in particular Willem de Boer and Geert Meun, whose consistent and articulate criticism of the Plaice Box is reflected in the current manuscript. As of writing the Plaice Box remains closed to large beam trawlers.

\section{REFERENCES}

Aarts, G., and Poos, J.J., 2009. Comprehensive discard reconstruction and abundance estimation using flexible selectivity functions. ICES J. Mar. Sci. 66, 763-771.

Anon., 1913. Meeting of the Plaice Commission 1912. Rapp. P.-v. Cons. int. Explor. Mer. XV, 102-122.

Anon., 1921. Recommendation of the Plaice Committee. Rapp. P.-v. Cons. int. Explor. Mer. XXVII, 50-60.

Asch, R.A. and Collie J.S., 2008. Changes in a benthic megafaunal community due to disturbance from bottom fishing and the establishment of a fishery closure. Fish. Bull. 106, 438-456.

Babcock, R., Kelly, S., Shears, N., Walker, J., and Willis, T., 1999. Changes in community structure in temperate marine reserves. Mar. Ecol.-Prog. Ser. 189:125134.

Beare, D., Rijnsdorp, A.D., van Kooten, T., Fock, H.O., Schröder, A., Kloppmann, M., Witbaard, R., Meesters, E., Schulze, T., Blaesbjerg, M., Damm, U., Quirijns, F., 
2010. Study for the Revision of the Plaice Box - Final Report. IMARES. Report $\mathrm{C} 002 / 10$.

Berghahn, R., Waltemath, M., and Rijnsdorp, A.D., 1992. Mortality of fish from the bycatch of shrimp vessels in the North Sea. J. Appl. Ichth. 8, 293-306.

Beukers-Stewart, B.D., Jenkins, S.R., and Brand, A.R., 2001. The efficiency and selectivity of spring-toothed scallop dredges: A comparison of direct and indirect methods of assessment. J. Shellfish Res. 20, 121-126

Carr M.H. and Reed D.C., 1992. Conceptual issues relevant to the design of marine harvest refuges: Examples from temperate reef fishes. Can. J. Fish. Aquat. Sci. 50, 2019-2028.

Charles, A., and Wilson, L., 2009. Human dimensions of Marine Protected Areas. ICES J. Mar. Sci. 66, 6-15

Claudet, J., D. Pelletier, J. Y. Jouvenel, F. Bachet, and R. Galzin. 2006. Assessing the effects of marine protected area (MPA) on a reef fish assemblage in a northwestern Mediterranean marine reserve: Identifying community-based indicators. Biol. Cons. 130: 349-369.

Codling, E.A., 2008. Individual-based movement behaviour in a simple marine reservefishery system: Why predictive models should be handled with care. Hydrobiologia $606,55-61$

Dinmore, T.A., Duplisea, D.E., Rackham, B.D., Maxwell, D.L., and Jennings, S., 2003. Impact of a large-scale area closure on patterns of fishing disturbance and the consequences for benthic communities. ICES J. Mar.Sci. 60, 371-380

Eastwood, P. D., Mills, C.M., Aldridge, J. N., Houghton, C. A., and Rogers, S. I.. 2007. Human activities in UK offshore waters: an assessment of direct, physical pressure on the seabed. ICES J. Mar. Sci. 64:453 -463.

Gell F.R. and Roberts C.M, 2003. Benefits beyond boundaries: the fishery effects of marine reserves. Trends Ecol. Evol. 18, 448-455

Greenstreet, S. P. R., Armstrong, E., Mosegaard, H., Jensen, H., Gibb, I. M., Fraser, H. M., Scott, B. E., Holland, G. J., and Sharples, J.. 2006. Variation in the abundance of sandeels Ammodytes marinus off southeast Scotland: an evaluation of area- 
closure fisheries management and stock abundance assessment methods. ICES J. Mar. Sci. 63:1530.

Grift, R., Tulp, I., Clarke, L., Damm, U., McLay, A., Reeves, S., Vigneau, J., and Weber, W.. 2004. Assessment of the ecological effects of the Plaice Box : Report of the European Commission Expert Working Group to evaluate the Shetland and Plaice boxes. European Commission. Retrieved June 18, 2009, from http://library.wur.nl/WebQuery/wurpubs/333735.

Hall, S.J. 1998. Closed areas for fisheries management - the case consolidates. Trends Ecol.Evol. 13: 297-298.

Halpern, B. S., Walbridge, S., Selkoe, K. A., Kappel, C. V., Micheli, F., D' Agrosa, C., Bruno, J. F., et al. 2008. A global map of human impact on marine ecosystems. Science, 319: 948-952

Hastings, A. and Botsford, L.W. 2003. Comparing Designs of Marine Reserves for Fisheries and for Biodiversity. Ecol. Appl. 13, 65-70.

Heath, M., and Beare, D., 2008. New primary production in northwest European shelf seas 1960-2003. Mar. Ecol. Progress. Ser. 363, 183-203.

Hermsen, J.M., Collie J.S. and Valentine P.C., 2003. Mobile fishing gear reduces benthic megafaunal production on Georges Bank. Mar. Ecol. Prog. Ser. 260, 97-108

Hiddink, J. G., Jennings, S., Kaiser, M. J., Queirós, A. M., Duplisea, D. E., and Piet, G. J. . 2006. Cumulative impacts of seabed trawl disturbance on benthic biomass, production, and species richness in different habitats. Can. J. Fish. Aquat. Sci. 63, 721-736.

Hiddink, J. G., Rijnsdorp, A. D., and Piet, G.. 2008. Can bottom trawling disturbance increase food production for a commercial fish species? Can. J. Fish. Aquat. Sci. 65:1393-1401.

Hiddink, J.G., Johnson, A.F., Kingham, R., and Hinz, H., 2011. Could our fisheries be more productive? Indirect negative effects of bottom trawl fisheries on fish condition. J. Appl. Ecol. 48, 1441-1449.

Higgins R.M., Vandeperrea F., Perez-Ruzafab A., and Santosa R.S., 2008. Priorities for fisheries in marine protected area design and management: Implications for 
artisanal-type fisheries as found in southern Europe. J. Nat. Cons. 16, 222-233

Horwood, J.W., Nichols, J.H., and Milligan, S. 1998. Evaluation of closed areas for fish stock conservation. J. Appl. Ecol. 35, 893-903.

ICES, 1987. Report of the ad-hoc meeting of the North Sea flatfish working group. ICES IJmuiden. CM 1987/Assess 14

ICES, 1994. Report on the Study Group on the Plaice Box, Charlottenlund, 12-15 April 1994. ICES CM 1994/Assess:11:45 pp

ICES, 1999. Report of the Workshop on the Evaluation of the Plaice Box. IJmuiden, 22-25 June 1999. ICES CM 1999/D:6.

ICES, 2011. Report of the Working Group on the Assessment of Demersal Stocks in the North Sea and Skagerrak (WGNSSK). ICES, Copenhagen.

Jennings, S., 2009. The role of marine protected areas in environmental management.

ICES J. Mar. Sci 66, 16-21

Jennings, S., and Kaiser, M.J. 1998. The effects of fishing on marine ecosystems. Adv. Mar. Biol. 34, 201-352.

Kaiser, M.J., Clarke, K.R., Hinz, H., Austen, M.C.V., Somerfield, P.J., and Karakassis, I., 2006. Global analysis of response and recovery of benthic biota to fishing. Mar. Ecol.-Prog. Ser. 311, 1-14

Kaiser, M. J. 2005. Are marine protected areas a red herring or fisheries panacea? Can J. Fish. Aquat. Sci. 62, 1194-1199.

Kraus, G., Pelletier, D., Dubreuil, J., Mollmann, C., Hinrichsen, H. H., Bastardie, F., Vermard, Y., and Mahevas, S., 2009. A model-based evaluation of Marine Protected Areas: the example of eastern Baltic cod (Gadus morhua callarias L.). ICES J. Mar. Sci. 66, 109-121

Laurel, B., and Bradbury, I.. 2006. Big concerns with high latitude marine protected areas (MPAs): trends in connectivity and MPA size. Can J. Fish. Aquat. Sci. 63:26032607.

Lindeboom, H., and Bäck, S.. 2005. Establishing coastal and marine reserves — with the emphasis on fisheries. Pages 103-117 in Managing European Coasts. Retrieved 
March 31, 2009, from http://dx.doi.org/10.1007/3-540-27150-3_5.

Lindholm, J., Auster, P. and Valentine, P., 2004. Role of a large marine protected area for conserving landscape attributes of sand habitats in Georges Bank (NW Atlantic). Mar. Ecol. Prog. Ser. 269, 61-68

Lorenzen, K., and Enberg, K., 2002. Density-dependent growth as a key mechanism in the regulation of fish populations: evidence from among-population comparisons. Proc. R. Soc. B: Biol. Sci. 269, 49-54..

Mielck, W., 1926. Die Sperrung der Jungschollengründe gegen die grosse Trawlfischerei. Ber. dt. wiss. Kommission Meeresforsch. II, 9-39.

Miethe, T., Dytham, C., Dieckmann, U., and Pitchford, J. W., 2010. Marine reserves and the evolutionary effects of fishing on size at maturation. ICES J. Mar. Sci. 67, 412425.

Modin, J., and Pihl, L., 1994. Differences in growth and mortality of juvenile plaice, Pleuronectes platessa L., following normal and extremely high settlement. Neth. J. Sea Res. 32, 331-341.

Murawski, S., Brown, R., Lai, H., Rago, P., and Hendrickson, L., 2000. Large-scale closed areas as a fishery-management tool in temperate marine systems: The Georges Bank experience. Bull. Mar. Sci. 66, 775-798.

Murawski S.A., Wigley S.E., Fogarty M.J., Rago, P.J. and Mountain, D.G., 2005. Effort distribution and catch patterns adjacent to temperate MPAs. ICES J.Mar.Sci. 62, $1150-1167$

Pastoors, M.A., Rijnsdorp, A.D., van Beek, F.A. 2000. Evaluation of the effects of a closed area in the North Sea ('Plaice Box') on the stock development of plaice (Pleuronectes platessa L.). ICES Journal of Marine Science, 57: 1014-1022

Pauly, D., Christensen, V., Guénette, S., Pitcher, T. J., Sumaila, U. R., Walters, C. J., Watson R., and Zeller, D., 2002. Towards sustainability in world fisheries. Nature 418:689-695.

Poos, J.J., Quirijns, F.J., and Rijnsdorp, A.D., 2010. Spatial segregation among fishing vessels in a multispecies fishery. ICES J. Mar. Sci. 67, 155-164

Ramsay, K., Kaiser, M.J., Rijnsdorp, A.D., Craeymeersch, J., and Ellis, J. 2000. The 
impact of beam trawling on populations of the benthic scavenger Asterias rubens L. pp 151-162. In Kaiser, M.J. and de Groot, S.J. (eds). Effects of fishing on nontarget species and habitats. Blackwell Science, London.

Röckmann, C., St.John, M.A., Schneider, U.A., and Tol, R.S.J., 2007. Testing the implications of a permanent or seasonal marine reserve on the population dynamics of Eastern Baltic cod under varying environmental conditions<http://edepot.wur.nl/142707> Fisheries Research 85 . p. 1 - 13.

Rijnsdorp, A.D. and van Beek, F.A. 1991. The effects of the plaice box on the reduction in discarding and on the level of recruitment of North Sea sole. ICES C.M. 1991/G:47

Rijnsdorp, A.D., Buys, A.M., Storbeck, F., and Visser, E.G. 1998. Micro-scale distribution of beam trawl effort in the southern North Sea between 1993 and 1996 in relation to the trawling frequency of the sea bed and the impact on benthic organisms. ICES J. Mar. Sci., 55, 403-419

Rijnsdorp, A.D. and van Leeuwen, P.I., 1996. Changes in growth of North Sea plaice since 1950 in relation to density, eutrophication, beam-trawl effort, and temperature. ICES J. Mar. Sci., 53, 1199-1213.

Rijnsdorp, A.D., and Vingerhoed, B. 2001. Feeding of plaice, Pleuronectes platessa, and sole Solea solea in relation to the effects of bottom trawling. J. Sea Res., 45, 219230

Rijnsdorp, A. D., Poos, J. J., Quirijns, F. J., HilleRisLambers, R., De Wilde, J. W., and Den Heijer, W. M,. 2008. The arms race between fishers. J. Sea Res., 60, 126138.

Shepherd, T. D., and Litvak, M.K., 2004. Density-dependent habitat selection and the ideal free distribution in marine fish spatial dynamics: considerations and cautions. Fish Fish. 5:141-152.

Sumaila, U. R., Guénette, S., Alder, J., and Chuenpagdee, R.., 2000. Addressing ecosystem effects of fishing using marine protected areas. ICES J. Mar. Sci. 57, 57: 752-760.

Teal, L.R., van Hal, R., van Kooten, T. , Ruardij, P., and Rijnsdorp, A.D. 2012. Bio- 
energetics underpins the spatial response of North Sea plaice (Pleuronectes platessa L.) and sole (Solea solea L.) to environmental change. Global Change Biol 18, 3291-3305.

Tulp, I., Bolle, L. J., and Rijnsdorp, A. D., 2008. Signals from the shallows: In search of common patterns in long-term trends in Dutch estuarine and coastal fish, Journal of Sea Research 60: 54-73, doi: 10.1016/j.seares. 2008.04.004

Van Beek, F. A., van Leeuwen, P.I., and Rijnsdorp, A.D.. 1990. On the survival of plaice and sole discards in the otter-trawl and beam-trawl fisheries in the North Sea. Neth. J. Sea Res. 26, 151-160.

Vandeperre, F., Higgins, R. M., Sánchez-Meca, J., Maynou, F., Goñi, R., Martín-Sosa, P., Pérez-Ruzafa, A., et al. 2011. Effects of no-take area size and age of marine protected areas on fisheries yields: a meta-analytical approach. Fish Fish., 12: 412426

van Keeken, O., van Hoppe, M., Grift, R., and Rijnsdorp, A.D.. 2007. Changes in the spatial distribution of North Sea plaice (Pleuronectes platessa) and implications for fisheries management. J. Sea Res. 57,187-197.

Verweij, M., andvan Densen, W., 2010. Differences in causal reasoning about resource dynamics and consequences for the participatory debate on North Sea fisheries. Mar. Pol. 34:1144-1155.

Weijerman, M., Lindeboom H., and Zuur A. F,. 2005. Regime shifts in marine ecosystems of the North Sea and Wadden Sea. Mar. Ecol. Progr. Ser. 298:21-39.

Wilson, B. 2008. Marine protected areas for coastal small cetaceans: The Moray Firth bottlenose dolphin experience. European Cetacean Society Special Publication Series, 48, 58-60.

Wiltshire, K. H., and Manly, B. F. J., 2004. The warming trend at Helgoland Roads, North Sea: phytoplankton response. Helgol. Mar. Res. 58:269-273.

Worm, B., Hilborn, R., Baum, J. K., Branch, T. A., Collie, J. S., Costello, C., Fogarty, M. J., et al. 2009. Rebuilding Global Fisheries. Science, 325: 578-585. 


\section{FIGURE LEGENDS}

Figure 1. Map of the Plaice Box and the areas used to assess its effect: (i) inside the PB and the $12 \mathrm{~nm}$ zone (in - in); (ii) inside the PB but outside the $12 \mathrm{~nm}$ zone (in - out); and (iii) outside the PB and inside the $12 \mathrm{~nm}$ zone (out - in); and (iv) outside the PB and outside the $12 \mathrm{~nm}$ zone (out - out).

Figure 2. Processes affecting the recruitment to the spawning stock biomass of plaice recruits. A cohort starts with the larval supply (1) to the nursery grounds within the Plaice Box (1a) and outside (1b). The 'neck tie' illustrates the growth rate (2) which affects the residence time of pre-recruits in the nurseries when they are exposed to discard mortality (3) and natural mortality (5) and the movement between nurseries (4).

Figure 3. Quarterly fishing effort (kW hours) of Dutch beam trawlers (top), Danish gillnetters (middle) and combined Danish, German and Dutch shrimpers (bottom) inside and outside the Plaice Box area between 1979 and 2008. The fishing effort inside the PB comprises the effort of the ICES rectangles covering the PB and includes effort exerted on the fishing grounds just outside the PB. The effort between 1979 and 1989 was reconstructed from the total fishing effort by fleet assuming a spatial allocation observed in the mid - 1970s.

Figure 4. Percentage of the landings of international fleet taken inside the PB since 1995.

Figure 5a. Distribution of fishing effort (log hours fished) of the major métiers fishing for demersal stocks in 2008 (less than or equal to $221 \mathrm{kWcombined} \mathrm{Danish,} \mathrm{Dutch} \mathrm{and} \mathrm{German}$ fleets) based on VMS registrations.

Figure 5b. Distribution of fishing effort (log hours fished) of the major métiers fishing for demersal stocks in 2008 (greater than $221 \mathrm{~kW}$ combined Danish, Dutch and German fleets) based on VMS registrations.

Figure 6. Time-trends in endobenthos, epibenthos, fish, and environmental data 1970-2010 inside the plaice box but outside the $12 \mathrm{~nm}$ zone (full line: in-out), inside the plaice box but inside the $12 \mathrm{~nm}$ zone (dotted line: in-in), and completely outside the PB (dashed line: outout). The horizontal bars indicate the periods of partial and complete closure.

Figure 7. Discard rates of plaice by year class in flatfish and mixed fisheries (upper panel) and number of 0-group plaice discarded in the shrimp fisheries (lower panel) based on Dutch, German and Danish data.

Figure 8: Spatial distribution of discard rates as percentage by weight from GLM model, left to right : Beam.80-99< = $221 \mathrm{~kW}$, Beam.80-99> $221 \mathrm{~kW}$, Otter trawls. 80$99<=221 \mathrm{~kW}$. Model results for large beam trawls extrapolate into the PB. 
Table 1. Percentage change in the yield and spawning stock biomass of plaice and sole due to the establishment of the Plaice Box (PB) as estimated in the successive advisory reports of ICES.

Plaice

Yield SSB Yield SSB

Closure

Management regime

period

Original Plaice Box advice (plaice: ICES, 1987; sole: Rijnsdorp and van Beek, 1991)

Q2+3

No fishing

Whole year No fishing

1994 Plaice box evaluation (ICES, 1994)

Whole year Zero discard fleets allowed

Whole year

Eurocutters allowed

22

26

6

9

2010 Plaice box evaluation (Beare et al., 2010)

Whole year Eurocutters allowed

$5 \quad 1$ 
Table 2. Processes included in the international plaice box evaluations carried out since 1987.

ICES 1987 ICES 1994 ICES 1999 Grift et al. Beare et al $2004 \quad 2010$

Ecological feed-back processes

\begin{tabular}{|c|c|c|c|c|c|}
\hline Growth & No & Yes & Yes & Yes & Yes \\
\hline Mortality & No & No & No & No & Yes \\
\hline Distribution & No & No & Yes & Yes & Yes \\
\hline \multicolumn{6}{|l|}{ Ecosystem changes } \\
\hline Recruitment & No & No & No & Yes & Yes \\
\hline Eutrophication & & No & No & Yes & Yes \\
\hline $\begin{array}{l}\text { Trawling impact benthic } \\
\text { productivity }\end{array}$ & & No & No & Yes & Yes \\
\hline Climate change & No & No & No & Yes & Yes \\
\hline \multicolumn{6}{|l|}{ Fleet dynamics } \\
\hline $\begin{array}{l}\text { Redistribution of fishing } \\
\text { effort after PB }\end{array}$ & Yes & Yes & Yes & Yes & Yes \\
\hline $\begin{array}{l}\text { Developments in fleet } \\
\text { capacity }\end{array}$ & No & No & No & Yes & Yes \\
\hline Competition among fleets & No & No & No & No & Yes \\
\hline
\end{tabular}


Table 3. Average annual fishing effort (million $\mathrm{kW}$ hours) in the Plaice Box and the percentage of the total effort exerted in the Plaice Box in three time periods of the main métiers targeting demersal species: A - 1984-1988 prior to the inception of the Plaice Box; B - 1989-1994 when the Plaice Box was closed during the $2^{\text {nd }}$ and $3^{\text {rd }}$ quarter; C $-1995-2008$ when the Plaice Box was closed year round. Data for Dutch métiers only. OTHER include the fishing gears: dredge; pots and seine.

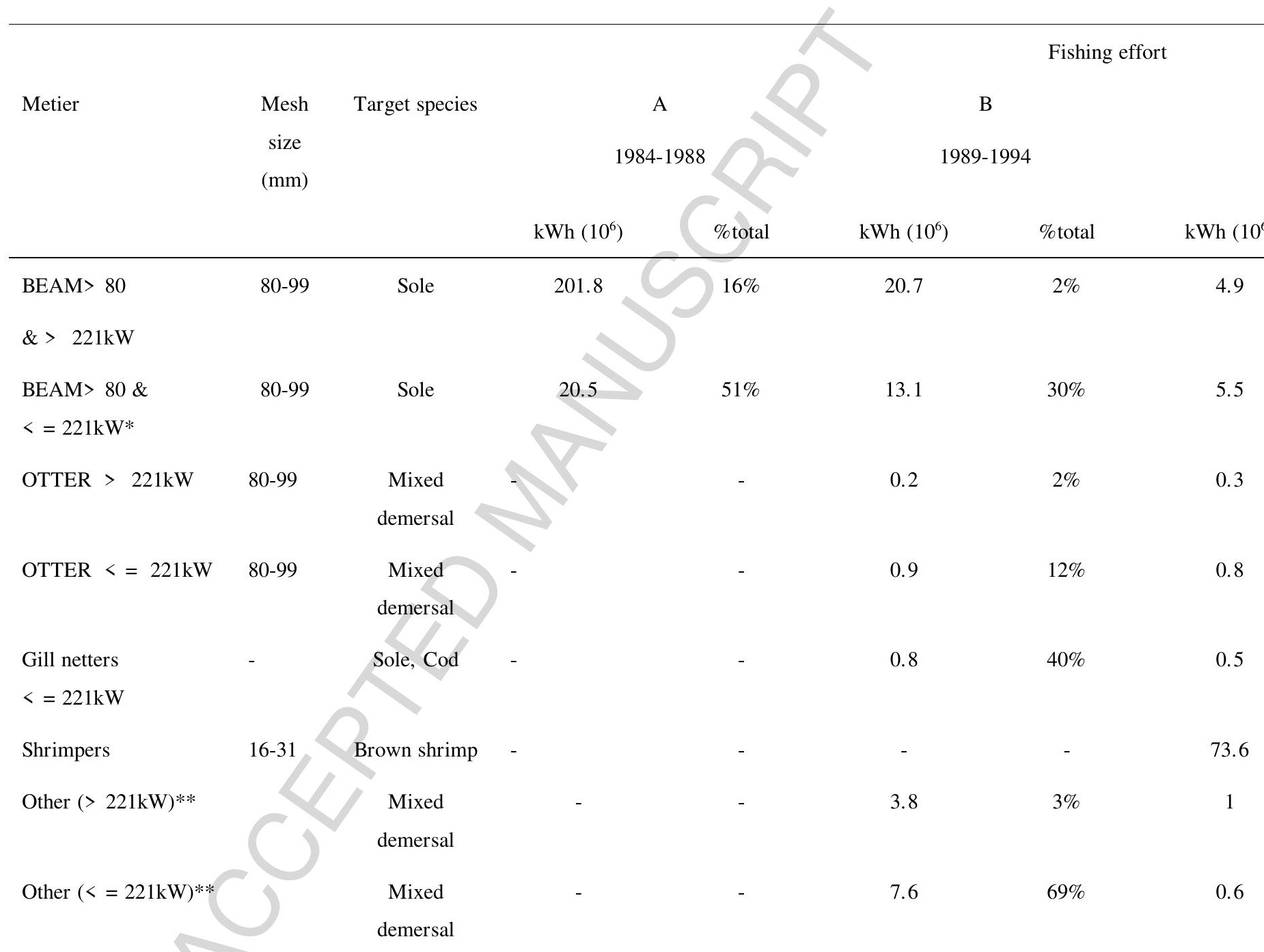


Table 4: Percentages of effort, catch and earnings inside the PB of total (in and outside the PB) effort, catch and earnings for small $(<=221 \mathrm{~kW})$ and large $(>221 \mathrm{~kW})$ vessels (mean of the years 2005 to 2008) for Denmark, Germany and the Netherlands combined, calculated using VMS data)

\begin{tabular}{lccc}
\hline Metier & Effort & Catch & Earnings \\
\hline $\begin{array}{l}\text { Engine power } \\
<=221 \mathrm{~kW}\end{array}$ & & & \\
BEAM 16-31 & 79 & 82 & 82 \\
BEAM 90-99 & 23 & 22 & 19 \\
BEAM > 100 & 64 & 73 & 71 \\
GILL- & 29 & 32 & 34 \\
TRAMMEL & & 14 & 14 \\
OTHER & 13 & 4 & 4 \\
OTTER 80-99 & 3 & 20 & 20 \\
OTTER > 100 & 20 & & \\
\hline Engine power & & 25 & \\
$>$ 221kW & 19 & & \\
GILL- & & 27 & \\
TRAMMEL & & & \\
OTHER & & & \\
\hline
\end{tabular}


Table 5: Discards by fleet outside and inside the Plaice Box based on Dutch, German and Danish (from Beare et al. 2010) and respective ICES estimates (ICES 2011) in tonnes per year.

\begin{tabular}{|c|c|c|c|c|c|c|c|c|c|c|}
\hline \multirow[b]{2}{*}{ metier } & \multicolumn{2}{|r|}{ year } & \multicolumn{2}{|c|}{2005} & \multicolumn{2}{|c|}{2006} & \multicolumn{2}{|c|}{2007} & \multicolumn{2}{|c|}{2008} \\
\hline & power & $\begin{array}{l}\text { Age } \\
\text { group }\end{array}$ & Outside & Inside & Outside & Inside & Outside & Inside & Outside & Inside \\
\hline BEAM.16-31 & $<=221 \mathrm{~kW}$ & age 0 & 274 & 1301 & 328 & 1149 & 233 & 1111 & 215 & 1058 \\
\hline BEAM.80-99 & $<=221 \mathrm{~kW}$ & age1+ & 9482 & 2106 & 6040 & 1714 & 7694 & 702 & 5599 & 555 \\
\hline BEAM.80-99 & $>221 \mathrm{~kW}$ & age1+ & 48285 & 0 & 42963 & & 46815 & 0 & 39030 & 0 \\
\hline OTTER.80-99 & $<=221 \mathrm{~kW}$ & age1+ & 1989 & 219 & 150 & 188 & 949 & 70 & 987 & 48 \\
\hline $\begin{array}{l}\text { TOTAL }(\mathrm{t}) \text { per } \\
\text { year }\end{array}$ & & & 63659 & & 53890 & & 57578 & & 47497 & \\
\hline ICES 2011 & & & 53876 & & 61846 & & 39435 & & 45875 & \\
\hline
\end{tabular}




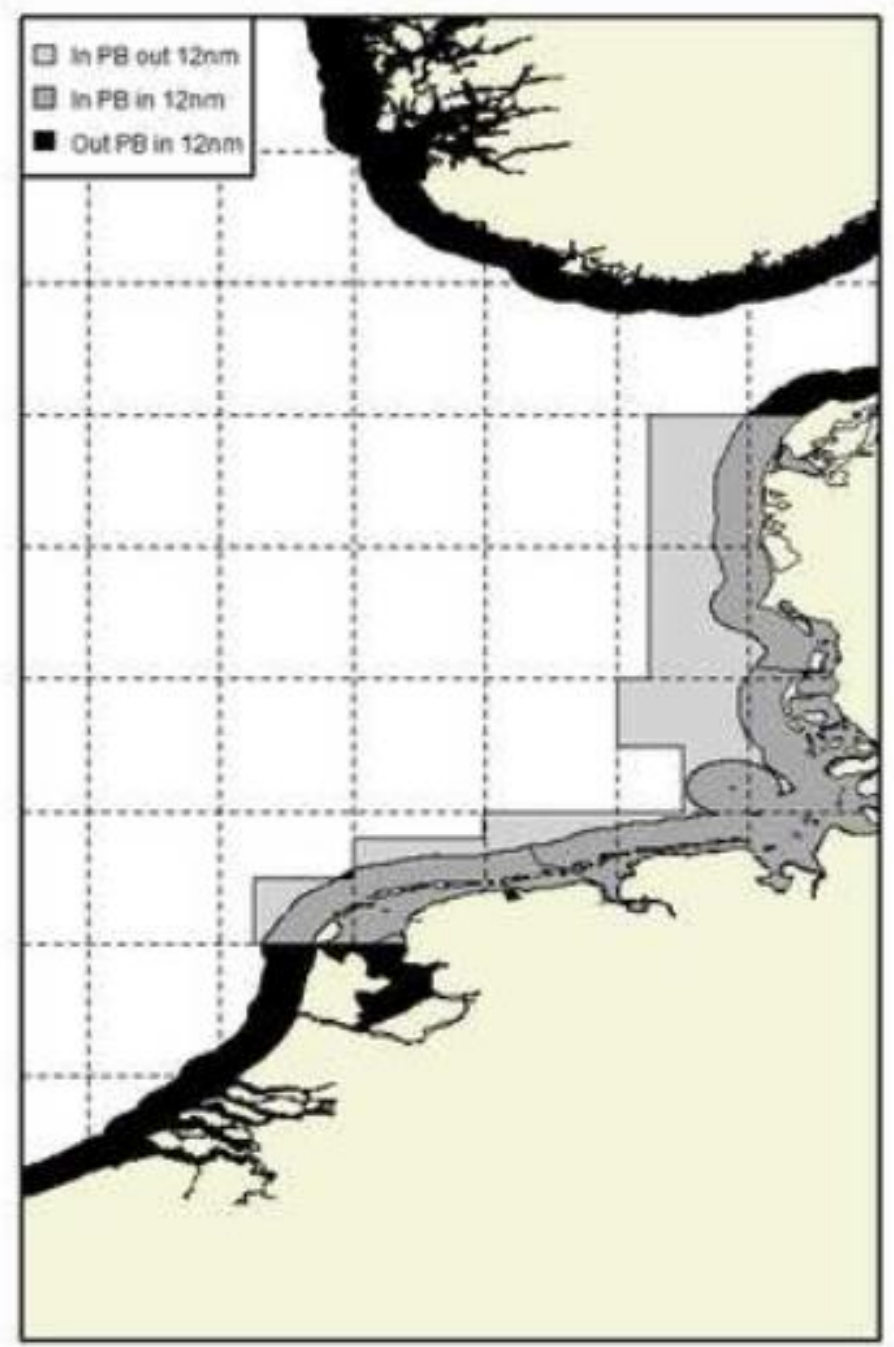

Fig. 1 


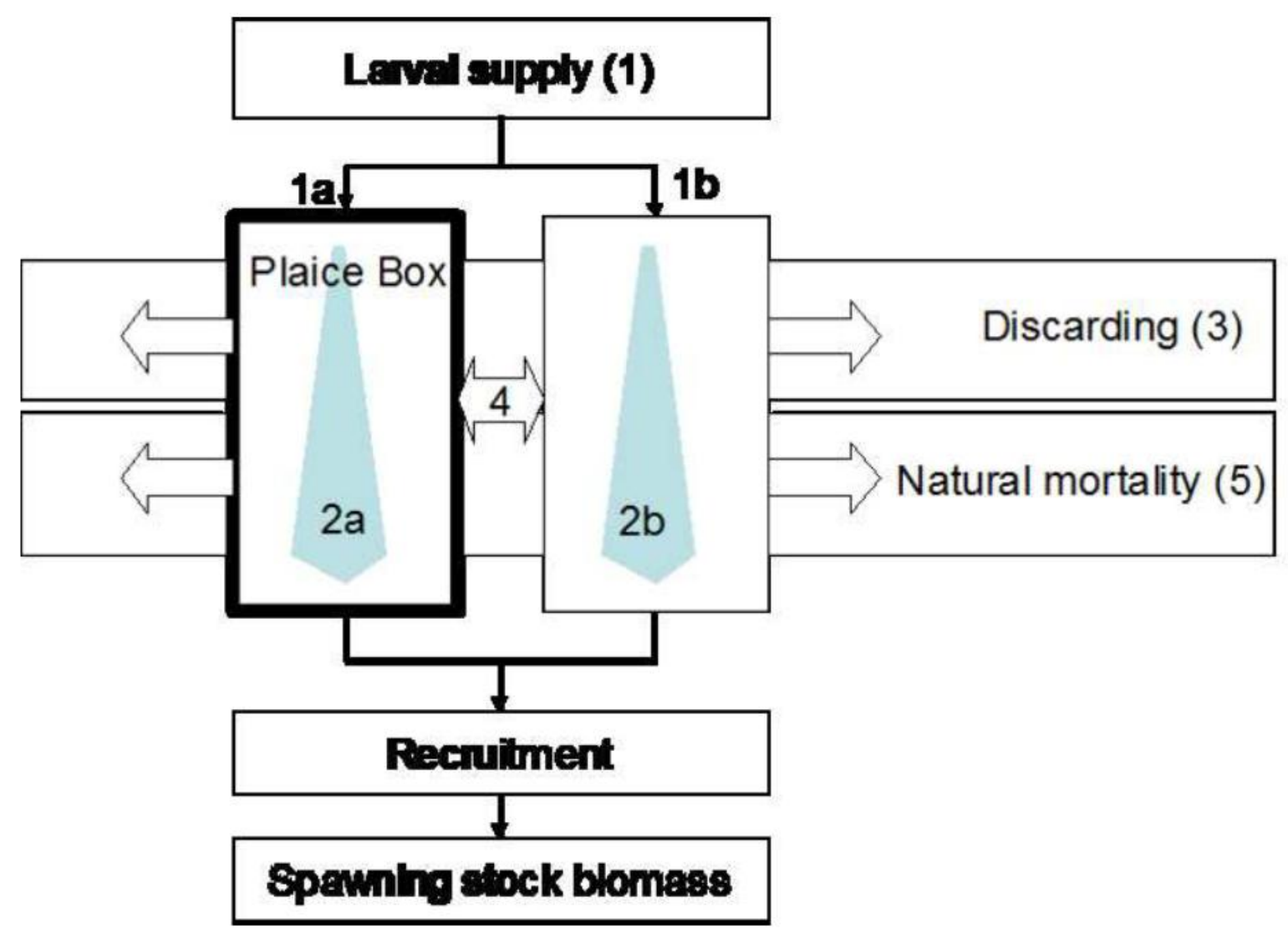

Fig. 2 

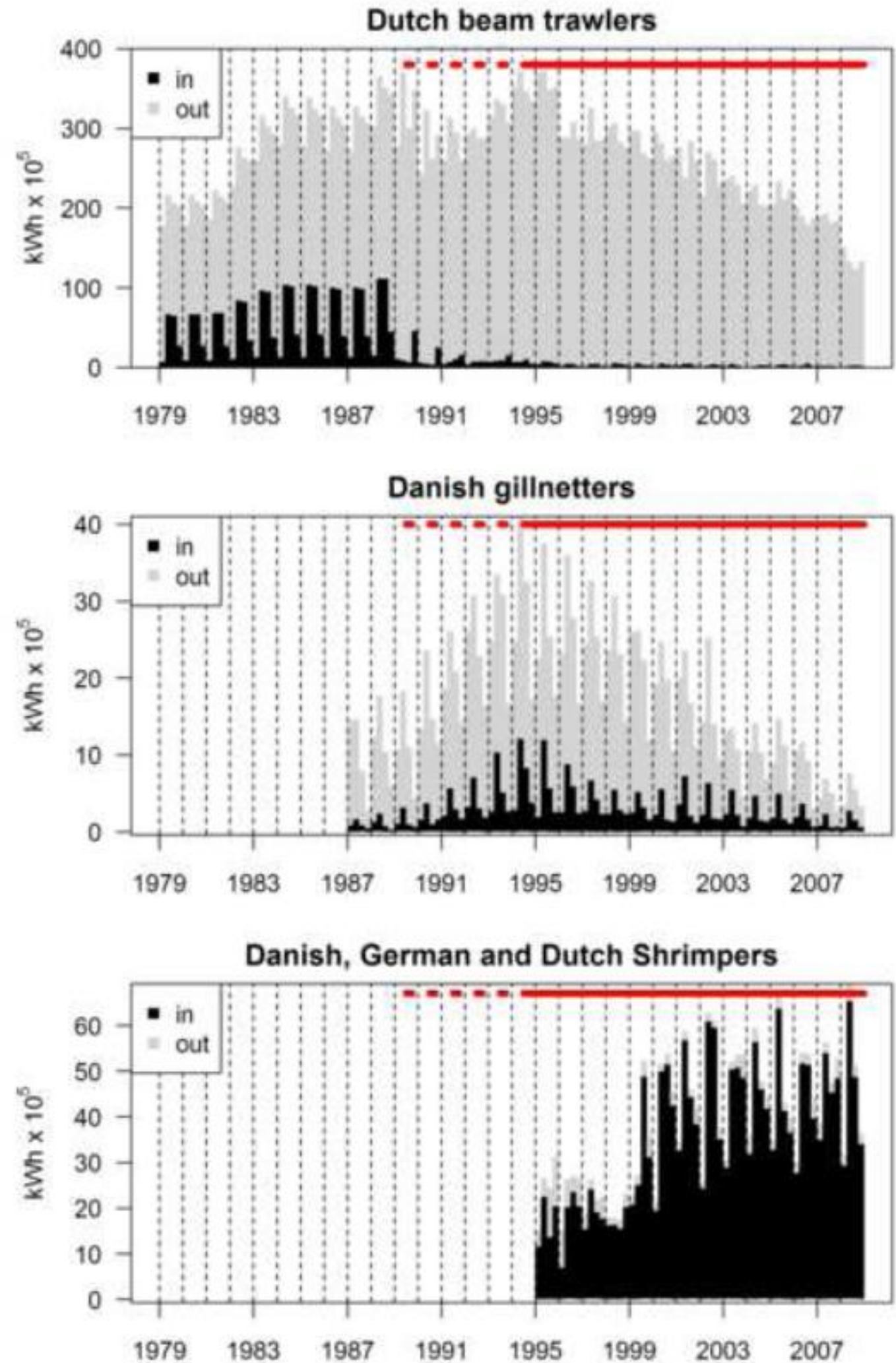

Fig. 3 


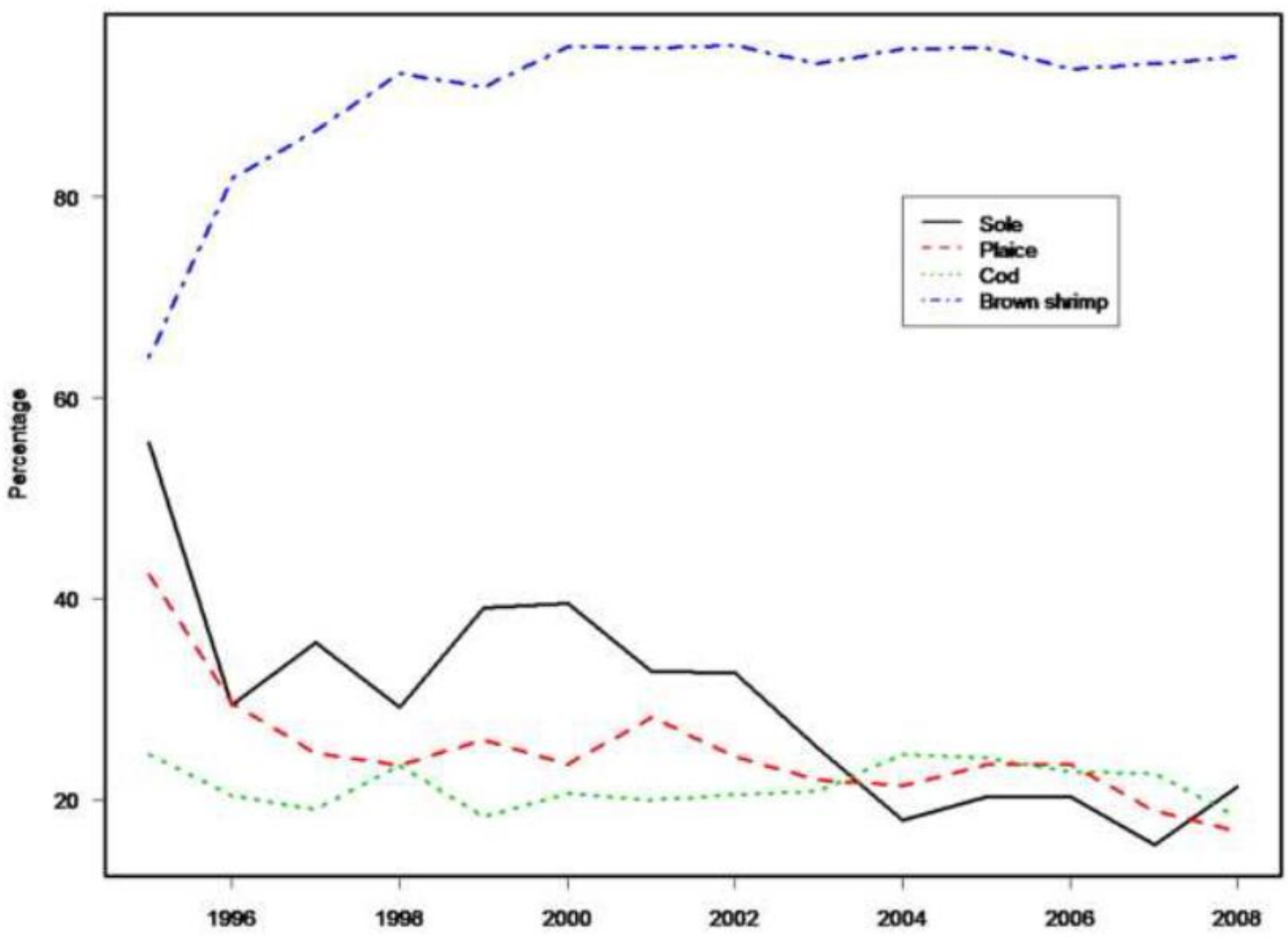

Fig. 4 

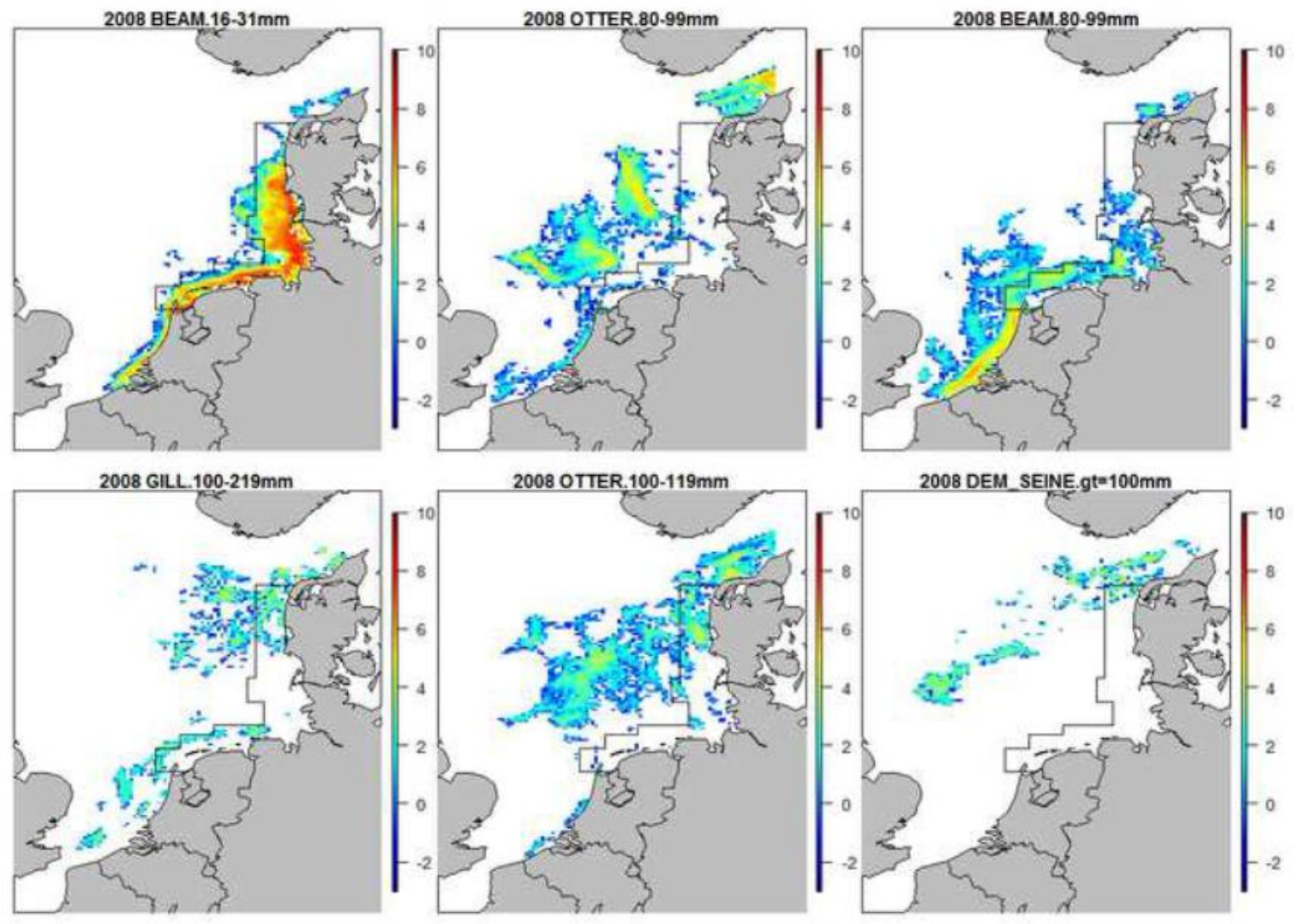

Fig. 5a 

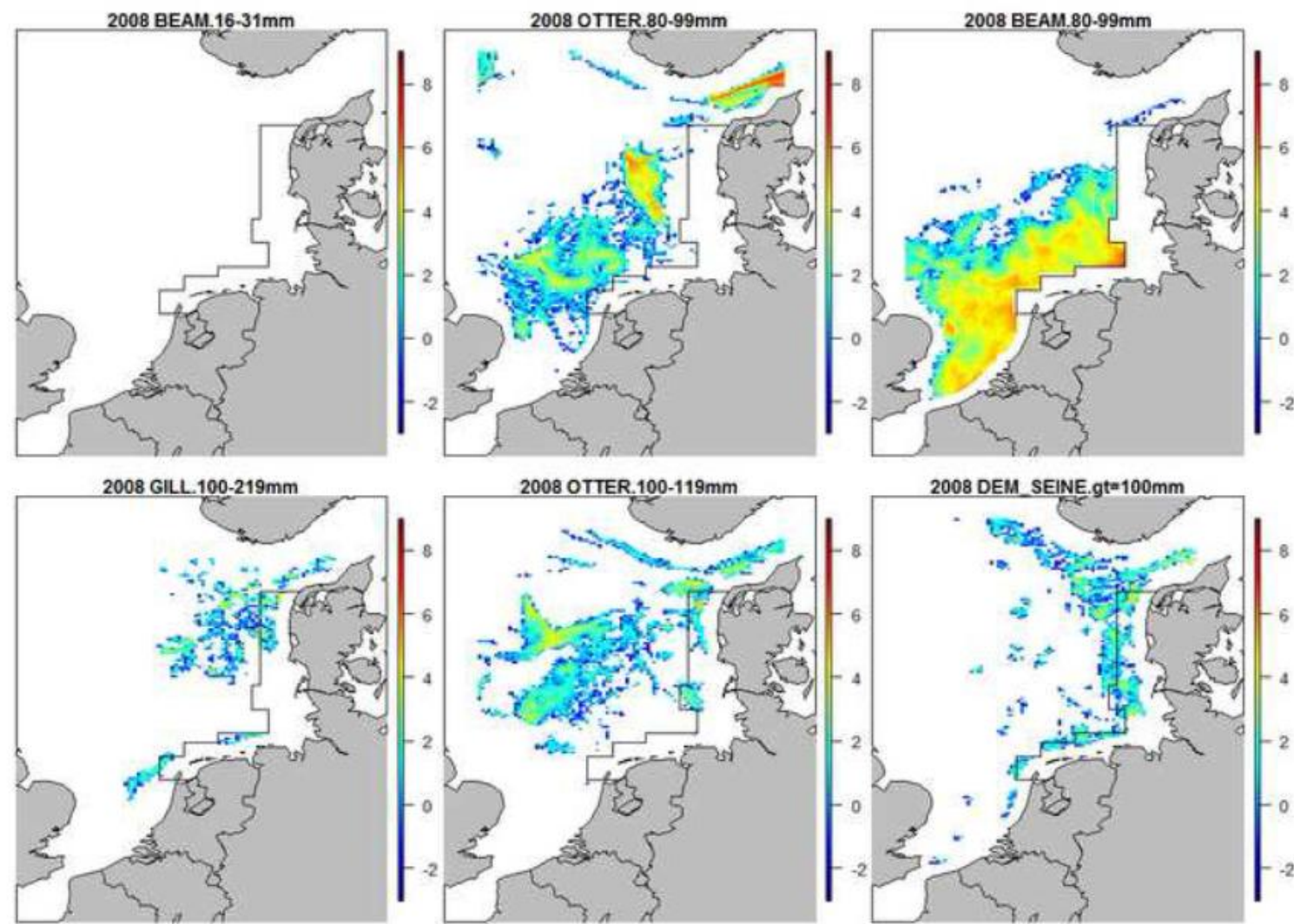

2008 OTTER. $100-119 \mathrm{~mm}$
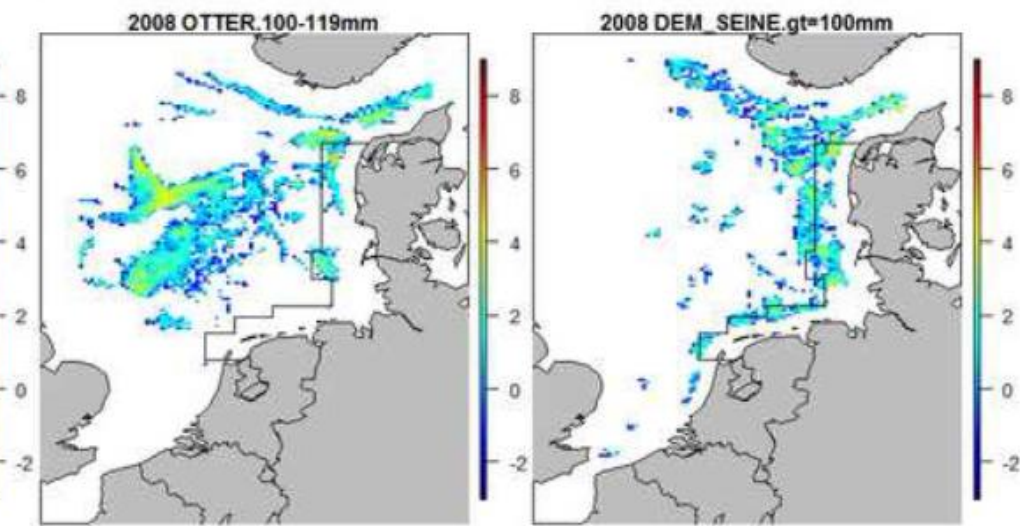

Fig. 5b 

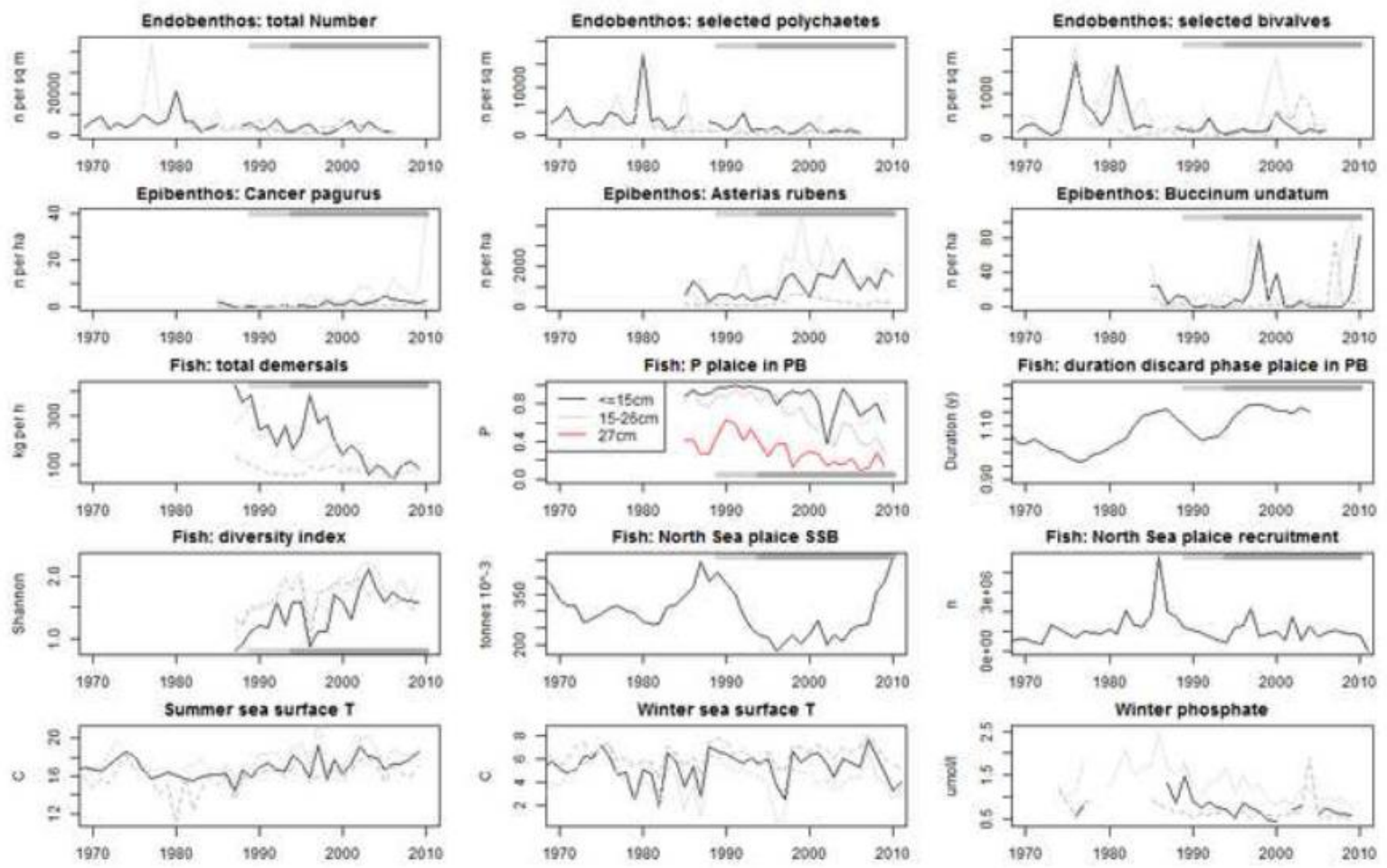

\section{- inout}

Fig. 6 

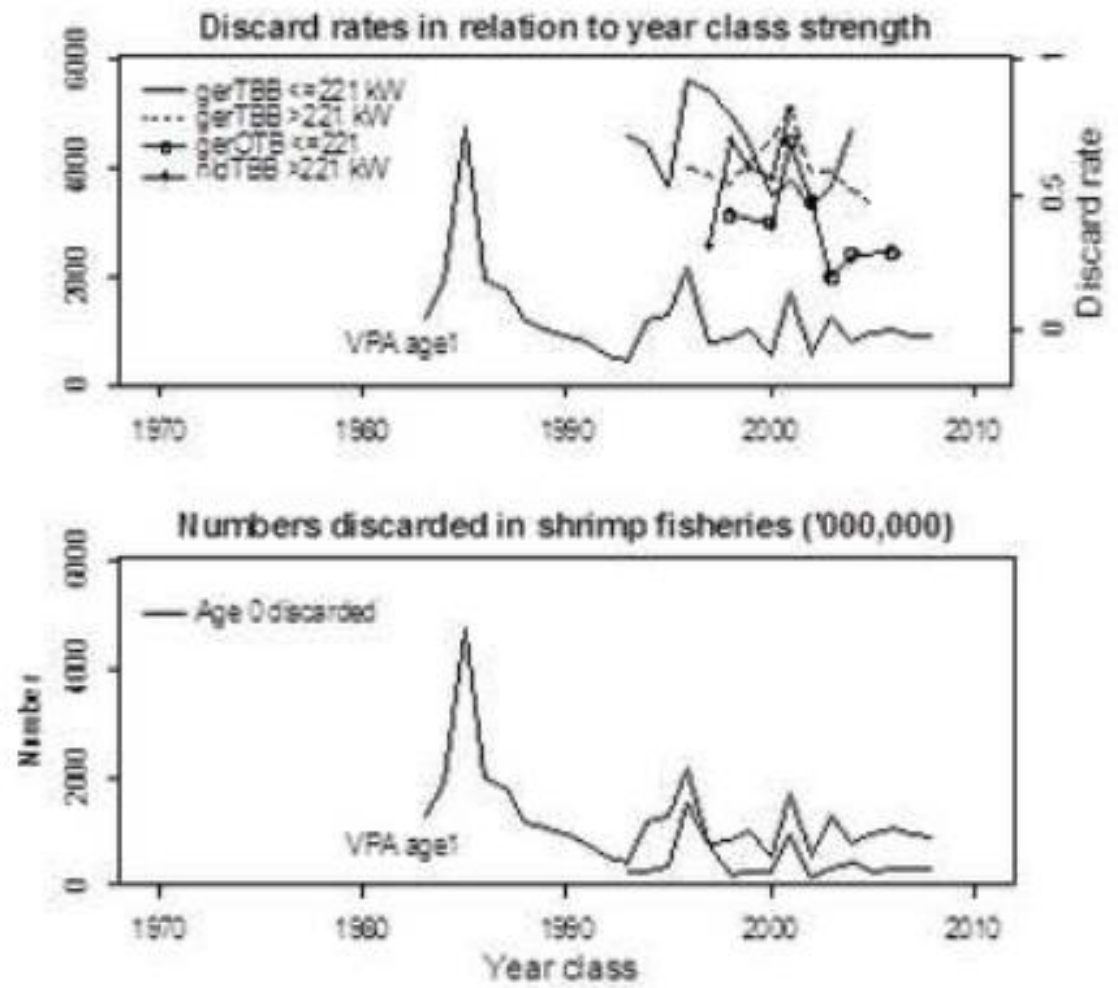

Fig. 7 

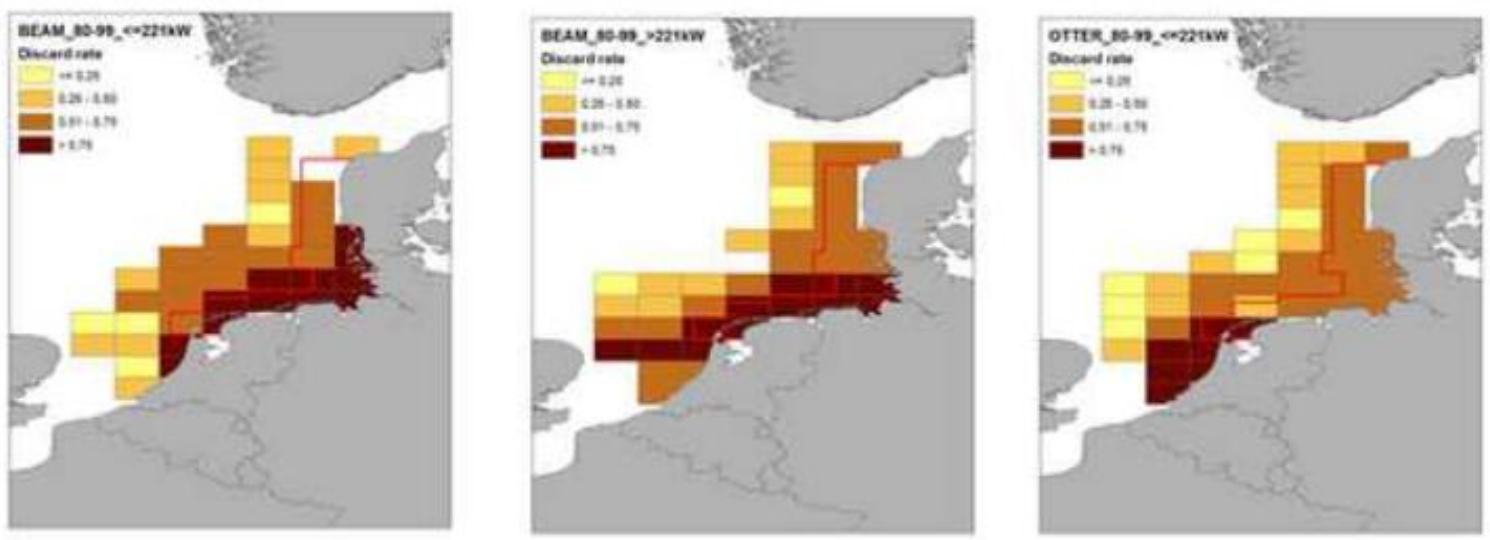

Fig. 8

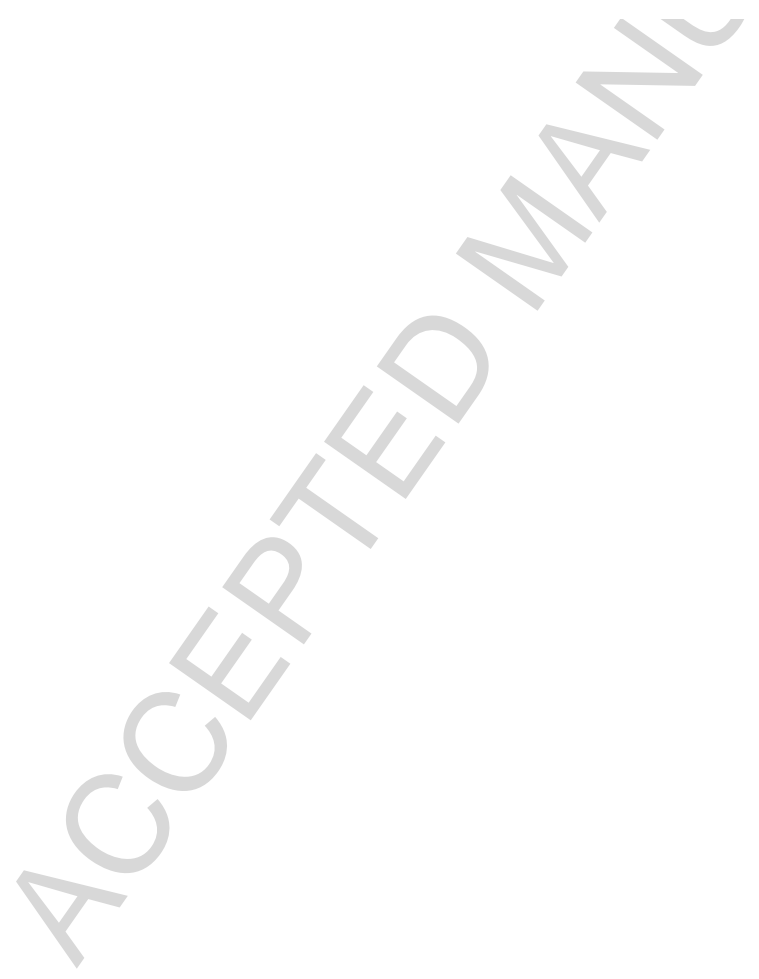




\section{Highlights}

Evaluating the effect of fishery closures: lessons learnt from the Plaice Box

1. We explore the Plaice Box as a fisheries management tool;

2. The Plaice Box was closed circa 20 years ago to protect juvenile plaice which then migrated outside;

3. The changes observed are discussed in the context of environmental and anthropogenic (e.g. fishing) drivers; 